\title{
FE ANALYSIS OF THE SYMPTOMATIC NAVICULAR - A CASE REPORT
}

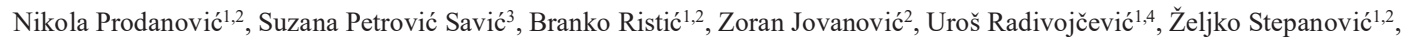
Đorđe Kolak ${ }^{2}$, Kristina Andrić ${ }^{5,6}$, Tijana Prodanović ${ }^{7}$, Bojan Stojanović1,8 and Nikola Andrić ${ }^{2}$

${ }^{1}$ University of Kragujevac, Faculty of Medical Sciences, Department of Surgery, Kragujevac, Serbia ${ }^{2}$ Clinical Centre Kragujevac, Clinic for Orthopedics and Traumatology, Kragujevac, Serbia

${ }^{3}$ University of Kragujevac, Faculty of Engineering, Department of Production Engineering, Kragujevac, Serbia ${ }^{4}$ Clinical Centre Kragujevac, Center for Plastic Surgery, Kragujevac, Serbia

${ }^{5}$ Clinical Centre Kragujevac, Center for Dermatovenerology, Kragujevac, Serbia

${ }^{6}$ University of Kragujevac, Serbia, Faculty of Medical Sciences, Department of Dermatovenerology ${ }^{7}$ Clinical Center Kragujevac, Pediatric Clinic, Kragujevac, Serbia

${ }^{8}$ Clinical Center Kragujevac, General and Thoracic Surgery Clinic, Kragujevac, Serbia

\section{FEM ANALIZA SIMPTOMATSKE NAVIKULARNE KOSTI -PRIIKAZ SLUČAJA}

Nikola Prodanović1,2, Suzana Petrović Savić ${ }^{3}$, Branko Ristić1,2, Zoran Jovanović2 ${ }^{2}$ Uroš Radivojčević1,4, Željko Stepanović1,2, Đorđe Kolak ${ }^{2}$, Kristina Andrićs, ${ }^{5,6}$ Tijana Prodanović 7 , Bojan Stojanović1,8 i Nikola Andrić ${ }^{2}$

${ }^{I}$ Univerzitet u Kragujevcu, Fakultet medicinskih nauka, Katedra za hirurgiju, Kragujevac, Srbija

${ }^{2}$ Klinički centar Kragujevac, Klinika za ortopediju i traumatologiju, Kragujevac, Srbija

${ }^{3}$ Univerzitet u Kragujevcu, Mašinski fakultet, Katedra za proizvodno mašinstvo, Kragujevac, Srbija

${ }^{4}$ Klinički centar Kragujevac, Centar za plastičnu hirurgiju, Kragujevac, Srbija

${ }^{5}$ Klinički centar Kragujevac, Centar za dermatovenerologiju, Kragujevac, Srbija

${ }^{6}$ Univerzitet u Kragujevcu, Fakultet medicinskih nauka, Katedra za dermatovenerologiju

${ }^{7}$ Klinički centar Kragujevac, Klinika za pedijatriju, Kragujevac, Srbija

${ }^{8}$ Klinički centar Kragujevac, Klinika za opštu i grudnu hirurgiju, Kragujevac, Srbija

\begin{abstract}
The accessory navicular $(A N)$ is a bony formation located on the medial side of the foot, proximal to the navicular and continuous with the posterior tibialis tendon. It emerges as a developmental variant due to the presence of the secondary ossification center adjacent to the primary center of the navicular. It is regarded as a physiological and anatomical variant. In most instances, this is an incidental finding. Radiographic values are used to define three types of AN based on its relationship with the navicular. The symptomatic AN causes pain in the medial portion of the bone, a decreased range of motion and discomfort with shoe wearing. In case of recurrent symptoms, following an inadequate diagnosis and treatment, it can result in acquired flatfoot. Our case study examined the condition of asymptomatic AN in a young man with both flatfeet, who was initially treated conservatively, and then, after the failed response to the therapy, surgically. Following the Kidner procedure (excision with the reattachment of the insertion in the posterior tibialis tendon) and rehabilitation, the patient reports no subjective symptoms in the period of 12month monitoring. An objective examination was conducted with the use of FE analysis during weight-bearing. We determined a reduction in total weight-bearing and the pressure distribution to the lateral side of the foot, metatarsal, and the heel region.
\end{abstract}

Keywords: Symptomatic accessory navicular; Tibialis posterior; the Kidner procedure; FE Analysis.

\section{SAŽETAK}

Akcesorna navikularna kost (ANK) stopala je koštana formacija lokalizovana u medijalnom delu stopala, proksimalno od navikularne kosti, u kontinuitetu tetive tibijalis posterior-a. Nastaje kao varijacija u razvoju, usled prisustva sekundarnog osifikacionog centra u blizini primarnog centra navikularne kosti $i$ smatra se fiziološkom anatomskom varijacijom, koja se najčešće nalazi kao uzgredan nalaz. Opisana su tri tipa ANK prema radiografskim kriterijumima, zasnovanim na odnosu sa navikularnom kosti. Simtomatska ANK najčešće izaziva bol u medijalnom delu stopala, otežanu pokretljivost i neprijatnost pri nošenju obuće, ali ukoliko tegobe traju dugo, bez adekvatno postavljene dijagnoze $i$ tretmana, može biti uzrok nastanka stečenog ravnog stopala. Naš prikaz slučaja se odnosi na stanje simptomatske ANK kod mladog muškarca sa obostranim ravnim stopalima, inicijalno tretiran neoperativno, a potom, nakon neuspešnog odgovora na terapiju, hirurški. Nakon učinjene Kidner-ove procedure (ekscizija sa replantacijom insercije tetive tibialis posterior-a) i rehabilitacionog perioda, pacijent je bez subjektivnih tegoba, u periodu praćenja od 12 meseci, dok je objektivno ispitivanje izvršeno FEM analizom opterécenja na stopalu i utvrđeno je smanjeno ukupno opteréénje, kao i preraspodela pritiska prema lateralnom svodu stopala, metatarzalnu regiju i petu.

Ključne reči: Simptomatska akcesorna navikularna kost; Pes planus; Tibialis posterior; Kidner-ova procedura; FEM Analysis. 


\section{INTRODUCTION}

The accessory navicular (AN) is a bony formation located on the medial side of the foot, proximal to the navicular and continuous with the posterior tibialis tendon. It represents the second commonest accessory bone in the foot. The first one being the peroneal (Lat. os peroneum), and the third, the trigonal. (Lat. os trigonum) [1].

It emerges as a developmental variant due to the presence of the secondary ossification center adjacent to the primary center of the navicular. It is regarded as a physiological and anatomical variant and it occurs in $4-20 \%$ of the population [2]. In most instances, this is an incidental finding, however, usually after a trauma, intense physical activity, or in patients in certain occupations, it can cause serious symptoms, such as pain, a decreased range of motion, discomfort with shoe wearing, and flatfoot deformity. During the diagnosis, the presence of the accessory navicular needs to be considered because it is usually interpreted as the straining of the foot or the ankle joint [3]. Radiographic assessment is sufficient to define three types of the accessory navicular [4].

Tibialis posterior is a muscle of the lower leg that is responsible for plantar flexion of the foot, postural stability of the tarsals, and the formation of the medial arch. The tendon is adhered to the medial portion of the navicular [5]. Recurrent symptoms of the symptomatic navicular may cause damage to the posterior tibialis tendon. This causes abnormalities during the stance, function, and movement phase.

The symptomatic AN causes pain in the medial portion of the bone, a decreased range of motion, and discomfort with shoe wearing, however, in case of prolonged difficulties, inadequate diagnosis and treatment, it can result in acquired flatfoot. Persons who are predisposed to develop the accessory navicular are athletes, obese, or workers wearing uncomfortable shoes.

The diagnosis is commonly established after an exhaustive search of the clinical history and clinical examinations. Additional diagnoses are made by radiographs of the weight and non-weight foot, and CT or MRI visualization [6].

The treatment can be conservative or surgical. The conservative treatment is based on resting, reduced physical activity, wearing more comfortable shoes or orthotic insoles, and the use of analgesics. If the symptoms persist, corticosteroids are given locally or the foot is immobilized for six to eight weeks. The operative treatment is usually advised if nonoperative treatment is unsuccessful or in more active patients such as young athletes [7].

One of the methods for surgical treatment of $\mathrm{AN}$ is the Kidner procedure. Kidner's assumption is that the presence of AN modifies the position and biomechanics of the insertion of the posterior tibialis tendon. This causes weakness in the longitudinal arch of the foot and flatfoot [8]. The method of final elements (FE analysis) is included in the contemporary methods of numerical analyses. This method has been widely used in order to achieve objectivity of the success of different types of surgical treatment. Up to date, there are no cases in which FE analysis has been used to treat the symptoms of the accessory navicular bone.

The objective of this study is to show the case of the symptomatic accessory navicular bone, its treatment, and outcome after twelve-month monitoring, as well as the analysis of the stress in the period before and after the surgery. The aim is to direct attention and raise awareness of the symptoms and its early and accurate diagnosis, as well as the possibilities of its treatment. One of the proposed methods of treating these symptoms is the Kidner procedure, which includes the excision of the accessory navicular bone, after which, the insertion of the posterior tibialis tendon is removed and reattached to the lower side of the navicular bone.

\section{CASE REPORT}

A young seventeen-year-old male reported pain and swelling in the medial portion of the foot. He claims they have emerged spontaneously. The problems were present a couple of weeks ago with the increase in intensity and discomfort during long walks and physical activities. He was directed to an orthopedist for further examination and evaluation. The clinical examination determined the presence of a palpatory disease in the inner portion of the right foot, in the portion of the navicular bone, alongside the bony prominence, and the swelling in the aforementioned portion with no pain in the left foot. During the examination, the presence of pes planus was recorded. No signs provided the evidence of erythema or inflammation in the inner portion of the foot, in the zone of the bony prominence. Plantar and dorsal flexion (tested on the heel and toes) exacerbated pain. In the left foot, there were no symptoms during the examination except the pes planus deformity.

In the personal clinical history, there were no significant data related to the case.

Radiographs are sufficient to reveal the bony prominence in the affected foot. It is in a triangular shape and in the continuity of the proximal portion of the navicular (Figure 1a).

Baropodometric examinations of the weight-bearing are done before the surgery. A significant amount of stress is reported on the medial portion of the foot, i. e. on the longitudinal arch and toes.

The diagnosis of the symptomatic accessory navicular bone is established based on the findings from the clinical evaluation, radiographic images, and baropodometric examinations.

Since there are no data related to the previous symptoms in the patient's case history, the conservative treatment is advised, which included immobilization for the period of six weeks, the use of non-steroid anti-inflammatory medicine, physical therapy, resting, and wearing orthotic insoles. The response to the therapy was not positive since the pain and 
tenderness were recurrent during shoe wearing and walking. Hence, a decision was made to continue with the procedure surgically. The Kidner procedure was followed and the posterior tibial tendon was reattached (Figure 2). Afterwards, immobilization was used for the period of two weeks. After the surgery, the control radiographic images of the accessory navicular bone detected successful osteotomy (Figure 1b).

Figure 1. Radiographic images.

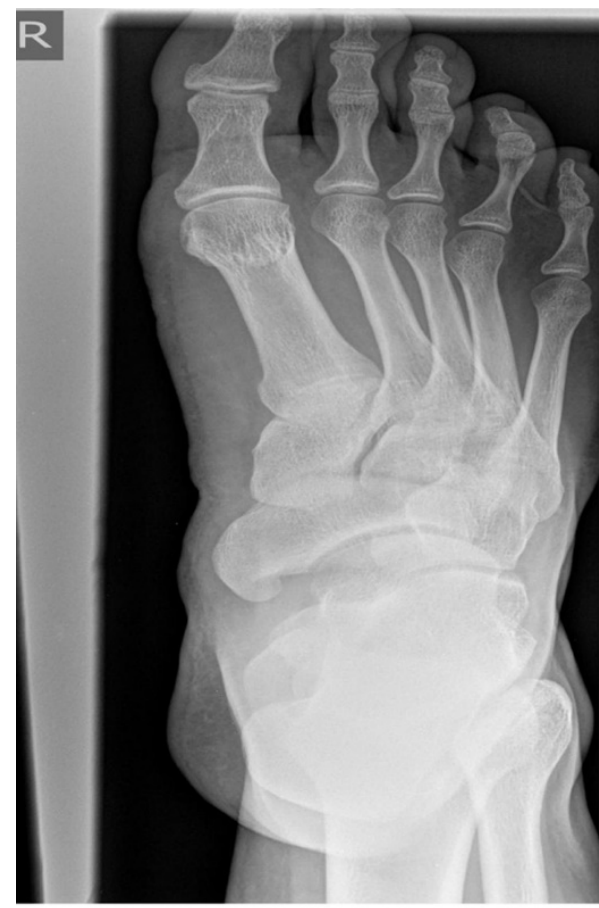

a) Before surgery

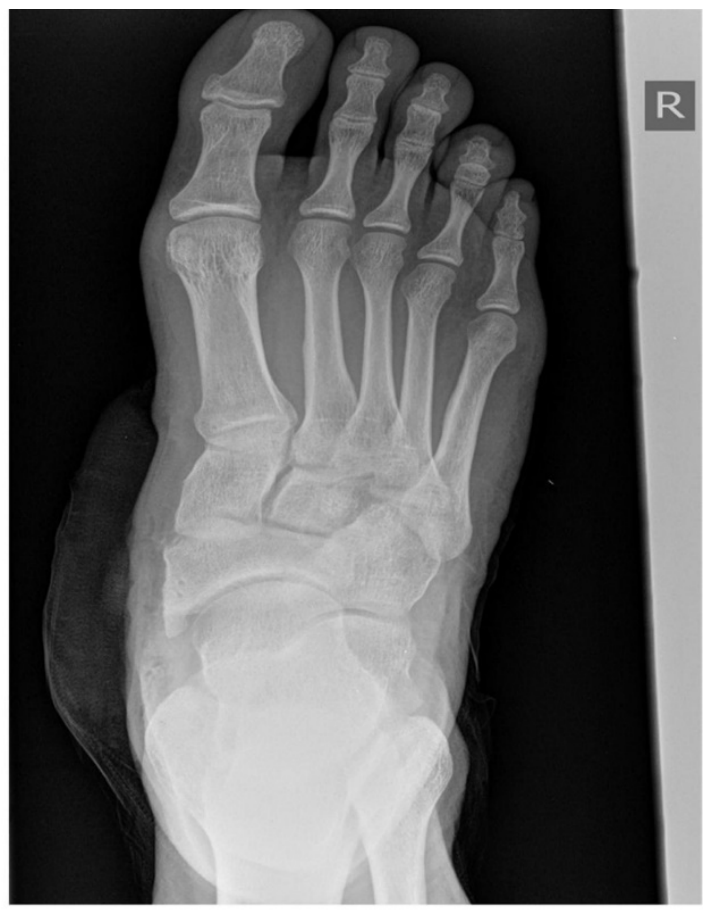

b) Following surgery

Figure 2. The Kidner Procedure.

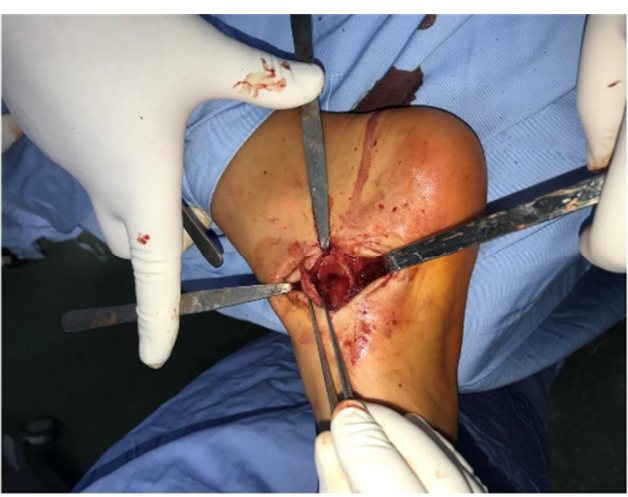

a) Excision of the navicular

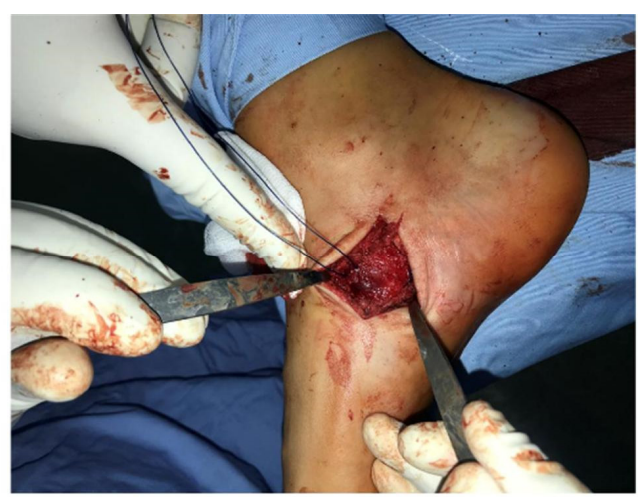

b) Reattachment of the posterior tibialis tendon

After the removal of the cast and the early rehabilitation period, baropodometric examinations of the involved foot are performed. Reduced stress in the medial portion of the foot and a more balanced pressure distribution to the lateral portion of the foot, metatarsal side, and the heel region were identified.

The stress in the foot was determined following the finite element (FE) analysis to the reconstructed model of the footprint before and after the surgery. The footprint was taken in the polyurethane foam. The examiner exerted a light pressure of the patient's foot onto the foam (Figure 3a). 
After taking the footprint, the foot was scanned using Sense 3D scanner with the resolution of $1 \mathrm{~mm}$ and the scanning range between 177 and $1828 \mathrm{~mm}$. The scanned footprint was reconstructed, processed, and optimized using Geomagic Design $\mathrm{X}$ software. The footprint model was exported to Catia V5 R21 software, in which a volumetric model was created and the FE analysis performed (Figure $3 \mathrm{~b}$ ).

Following the FE analysis, the case of static pressure onto the flat floor of the footprint before and after the surgery was considered (Figure 3c). The aforementioned models correspond to the experimental trials. During the examination, tetragonal finite elements were used.

The contact was established between the surface of the foot and the ground. The stress value equated to the weight of the patient $(77 \mathrm{~kg})$. Young's module of the footprint was 1.15 $\mathrm{MPa}$, Poisson's ratio 0.49, while Young's module of the ground was estimated $2000000 \mathrm{MPa}$, and Poisson's ratio 0.29 [9].

Figure 3. a) The footprint in the polyurethane foam

b) Process algorithm of the scanned foot

c) FE Analysis - Foot pressure onto the ground

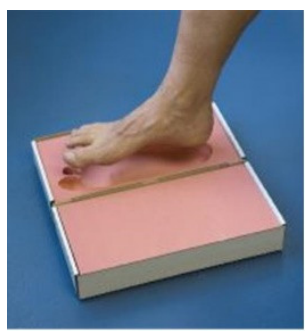

a)

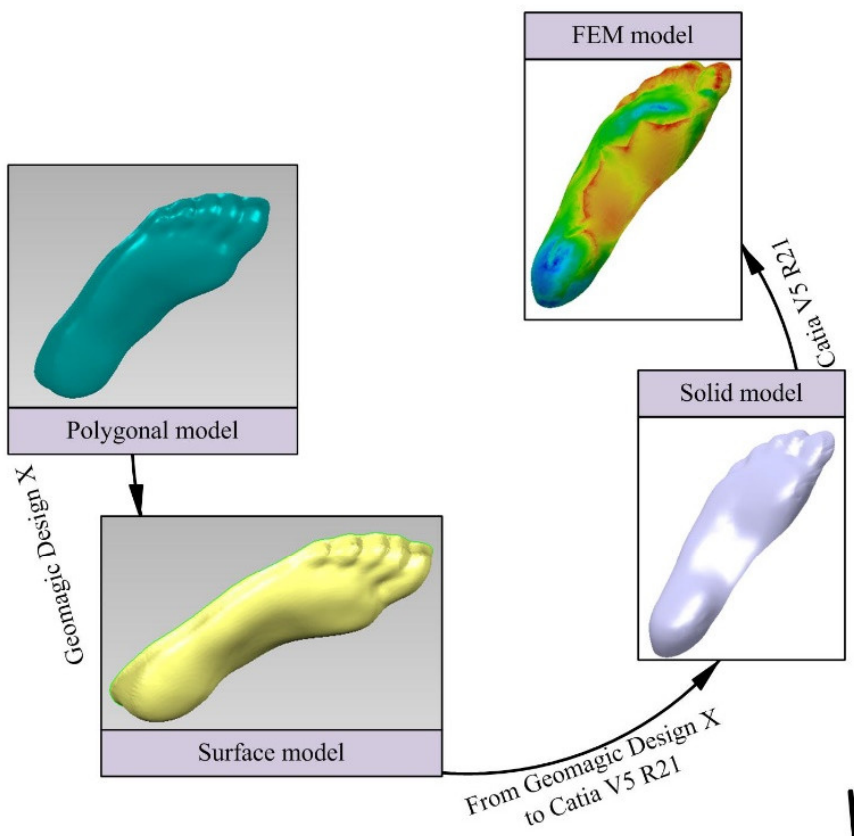

b)
Weight

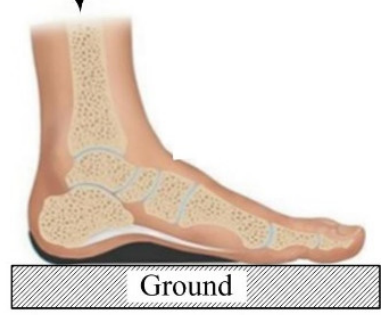

(https://www.peric-medikal.rs/kategorija/ortopedski-program/cipele-i-ulosci-za-obucu/?lang=lat)

(https://www.slideshare.net/akshayvagha/how-orthotic-insoles-can-alleviate-heel-and-foot-plantar-fasciitis)

The most significant stress value $(2,4 \mathrm{MPa})$ in the patient with AN symptoms before the surgery was located on the medial side of the foot, i.e. on the longitudinal medial arch and toes. According to the values of Von Mises stresses after the FE analysis (the values were between $0,112 \mathrm{MPa}$ and $0,00523 \mathrm{MPa}$ ). There was an insignificant amount of stress values on the heel region, metatarsal area, and the lateral portion of the foot (Figure 4a). These results point to the fact that the patient had an unequal stress distribution during standing on the affected foot, which caused the pain.

During the control examinations in the period of twelve months after the surgery, the patient reports no pain and symptoms in the portion of the involved foot, which the stress 
data show after the FE analysis. In other words, following the surgery, there is a stress redistribution onto the lateral portion of the foot, metatarsal, and the heel region with the significantly reduced values of the maximal stress. Hence, the maximal stress value is $0,676 \mathrm{Mpa}$. Moreover, there is a noticeable stress relief in the portion of the navicular, which results in the pain decrease in that portion (Figure $4 b$ ).

Figure 4. Von Mises stress.
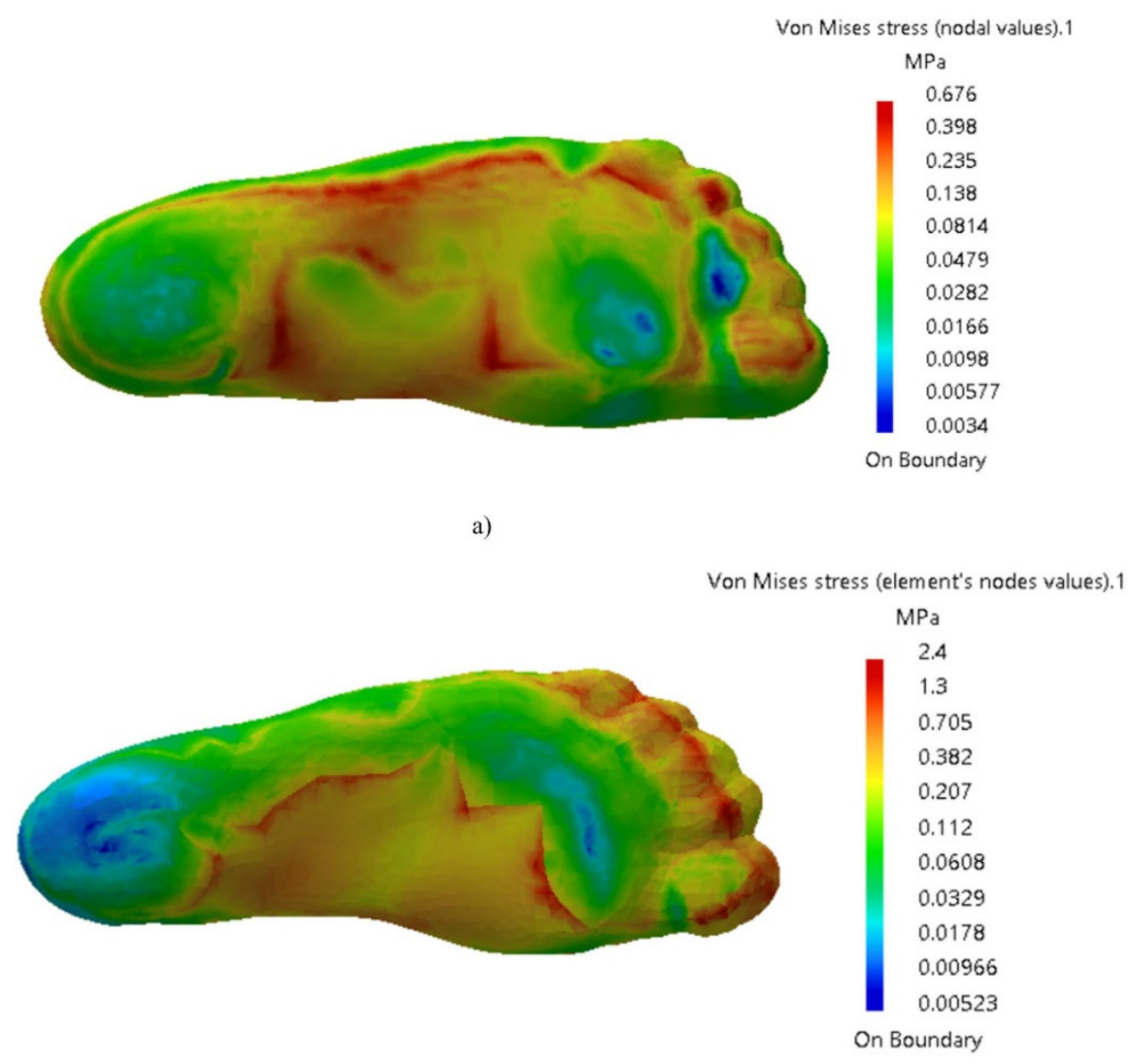

b)

a) Before surgery

b) Following surgery

\section{DISCUSSION}

The symptoms of the accessory navicular commonly emerge in front of the ankle joint and develop towards the inner side of the foot. Since the patient also had a flatfoot deformity, the stress on the foot was not equally distributed. The conservative treatment of the navicular symptoms commonly includes resting, comfortable shoe wearing, analgesics, and physical therapy, which was shown in the retrospective study conducted by the authors [10].

Many studies have been conducted related to the flatfoot classification, as well as to the analysis of the stress onto flatfoot by the use of the FE analysis or the plantar footprint analysis. In that sense, M. Costea at al. developed a methodology for classifying flatfoot based on the plantar footprint. The category of the foot is determined by the use of ChippauxSimark Index and Hallux-Valgus Angle [11]. Contrary to the aforementioned authors, C. Cifuentes-de la Portilla et al, as well as L.Shudong et al. used the FE model for the analysis of the stress onto the foot - the former analyzed the stress on the soft tissues with the flatfoot deformity, and the latter analyzed the foot deformities during standing. In both cases, the foot reconstruction was conducted based on the CT images of the non-affected foot $[12,13]$. In our study, the non-invasive methods of footprint scanning in a non-stress condition were employed. Similarly to the findings from the study by C. Cifuentes-de la Portilla et al, our study determined that the stress on the reconstructed footprint corresponded to the weight of the patient during the monopodial support [12].

The proper formats of pressure distribution in the foot are determined by examining the pressure in the foot, the analyses of plantar pressure, and the conducted FE analyses. A clinically healthy foot is considered when the stress in the metatarsal portion, heel region, and the lateral side of the foot 
is equally distributed $[14,15,16]$. The patients with flat foot deformity suffer most from a stress increase in the medial portion of the foot, i.e. in toes [15]. In our case, the patient has a flat foot deformity and the stress that is created in the foot during total support corresponds to the stress distribution found by other authors [15]. However, what seems characteristic for this case is that there is virtually no support in the heel zone, i.e. the whole patient's body weight is redistributed to the medial portion and toes. After the surgery of accessory navicular syndrome, the stress is significantly reduced and leads to the stress redistribution to the portions that would correspond to a healthy foot. Due to the flatfoot deformity, certain amount of stress is still distributed to the medial portion, however, its values are significantly reduced.

\section{REFERENCES}

1. Kalbouneh H., Alajoulin O., Alsalem M., Humoud N., Shawaqfeh J., Alkhoujah M., Abu-Hassan H., Mahafza W., et Badran D.: Incidence and Anatomical Variations of Accessory Navicular Bone in Patients with Foot Pain: A Retrospective Radiographic Analysis, Clinical Anatomy 2017, 30: 436-444

2. Romanowski C.A., Barrington N.A.: The accessory navicular - An important cause of medial foot pain, Clin Radiol 1992, 46:261-264

3. Mansoor S.N., Rathore F.A.: Symptomatic accessory navicular bone: A case series, The Egyptian Rheumatologist 2017

4. Gueye A.B., Niane M., Kinkpe C.V.A., Diop A.N., Daffe M., Dia R. et Abdoulaye N.: Symptomatic accessory navicular bone: A case report, Internation al Journal of Orthopaedics Sciences 2019, 5(4): 806-808

5. Pedowitz W.J., Kovatis P.: Flatfoot in the adult, $J \mathrm{Am}$ Acad Orthop Surg 1995, 3 (5):293-302

6. Tuthill H.L., Finkelstein E.R., Sanchez A.M., Clifford P.D., Subhawong T.K., Jose J.: Imaging of tarsal navicular disorders: A pictorial review, Foot Ankle Spec 2014, 7(3):211-225

7. Sullivan J.A., Miller W.A.: The relationship of the accessory navicular to the development of the flat foot, Clin Orthop Relat Res 1979, 144:233-237

8. Kim J., Day J., Seilern, J.: Outcomes Following Revision Surgery After Failed Kidner Procedure for Painful Accessory Navicular, Foot \& Ankle International 202

9. Taha Z., Norman M.S., Omar S.F.S., Suwarganda E.: A finite element analysis of a human foot model to simulate neutral standing on ground, ProcediaEng 2016, 147:240-245

10. Knapik D. M., Archibald H. D. Xie K. K., Liu R. W. A retrospective study on factors predictive of operative intervention in symptomatic accessory navicular, J Child Orthop. 2019 Feb 1; 13(1): 107-113.

11. Costea M., Sarghie B., Mihai A., Rezus E.: Classification of the eldery foot types based on plantar footprints, Procedia Engineering 2017, 181:36-43

\section{CONCLUSION}

The accessory navicular bone is commonly seen in everyday clinical praxis. In most instances, this is an incidental finding. The surgical treatment of the symptomatic accessory navicular is a therapy of choice in patients with an inadequate response to the conservative mode of treatment. The surgical treatment not only leads to the complete relief of symptoms, but also to the stress redistribution with the relief on the medial arch of the foot.

\section{ACKNOWLEDGEMENTS}

The results of this research are the part of the project supported by the Ministry of Education, Science and Technological Development (Serbia) Grant III-41007.

12. Cifuentes-de la Portilla C., Larrainzar-Garijo R., Bayod J.: Analysis of the main passive soft tissues associated with adult acquired flatfoot deformity development: A computational modeling approach, Journal of biomechanics 2019, 84: 183-190

13. Shudong L., Zhang Y., Gu Y., Lake M.J., Ren X.: Experimental studies and effective finite element modeling of foot deformation in standing, International Journal of Experimental and Computational Biomechanics 2018, 4(2/3), ISSN 1755-8735

14. Ozen M., Sayman O., Havitcioglu H.: Modeling and stress analyses of a normal foot-ankle and a prosthetic foot-ankle complex, Acta Bioeng Biomech 2013, 15(3):19-27

15. Petrovic Savic S., Lukic N., Prodanovic N., Devedzic G.: A Comparative FE Analysis of a Flat Foot with and without a Custom-made Orthotic Insole, 8th Mediterranean Conference on Embedded Computing (MECO), Budva, Montenegro, 2019, pp. 1-4,

16. Vijayaragavan E., Gopal T.V.: Biomechanical modeling of human foot using finite element methods, Indian journal of science and technology 2016, 9(31):1-5 